\title{
KSZTAŁT POLSKIEJ PEDAGOGIKI NARODOWEJ WEDŁUG WIKTORA WĄSIKA
}

\section{The Shape of Polish National Pedagogics according to Wiktor Wąsik}

S u $\mathrm{m} m$ a r y: The article aims to demonstrate the validity of Wiktor Wąsik's assertions regarding the existence of a national Polish pedagogy. An analysis of the views of these thinkers shows that there are many essential pedagogical features common across these scholars, even though they lived in different epochs. This analysis also allows us to see their work as both specifically Polish and simultaneously well-harmonized within European thought.

Ke y w or d s: Polish national pedagogics, Wiktor Wąsik, Sebastian Petrycy of Pilsno, Hugo Kołłątaj, Stanisław Staszic, Bronisław Trentowski

Określenie „narodowa pedagogika polska” może wywoływać skojarzenie z nacjonalistyczną tendencją występującą w teorii czy praktyce wychowawczej. Tymczasem nieco bliższe zapoznanie się z polską myślą, w ramach której pojawia się także refleksja nad wychowaniem, prowadzi do zupełnie innych wniosków. Autorem, który przełamując stereotypy, włączył do historiografii filozofii myśl pedagogiczną, był Wiktor Wąsik. Wyrażone przez tego, niesłusznie dziś zapomnianego, uczonego przekonanie o istnieniu poglądów, które można objąć kategorią wskazaną w tytule artykułu, zainspirowało powstanie tego tekstu. Ma on na celu ukazanie pewnych cech charakterystycznych, a więc kształtu naszej narodowej pedagogiki, pojawiających

${ }^{1}$ Ks. dr hab. Rafał Charzyński - adiunkt w Katedrze Historii Filozofii w Polsce, Wydział Filozofii, Katolicki Uniwersytet Lubelski Jana Pawła II. Adres do korespondencji: Al. Racławickie 14, 20-950 Lublin; e-mail: rafal.charzynski@kul.lublin.pl. 
się u myślicieli wskazanych przez Wąsika. Realizacji tego zadania podporządkowana jest struktura artykułu. W części pierwszej znajdzie się syntetyczny opis pedagogicznego systemu Sebastiana Petrycego z Pilzna, następnie zarysowana zostanie oświeceniowa filozofia wychowania ze szczególnym uwzględnieniem stanowisk protagonistów tego okresu: Stanisława Staszica i Hugona Kołłątaja, wreszcie przywołane zostaną poglądy Bronisława Ferdynanda Trentowskiego, dotyczące jego koncepcji narodowej pedagogiki.

W klasycznym, dwutomowym opracowaniu dziejów filozofii polskiej Wiktor Wąsik pisał o pewnej stałej tendencji występującej w naszej rodzimej refleksji dotyczącej wychowania, która uzasadnia tezę o istnieniu narodowej pedagogiki². Jej początki, zdaniem Wąsika, sięgają twórczości Petrycego z Pilzna, a zwieńczeniem jest filozoficzna pedagogika Bronisława Trentowskiego ${ }^{3}$. Pogląd przyznający palmę pierwszeństwa w tej dziedzinie właśnie Sebastianowi Petrycemu odbiega od rozpowszechnionej opinii, według której ojcami tradycji wychowania narodowego byli Stanisław Staszic i Hugo Kołłątaj ${ }^{4}$. W ujęciu Wąsika mielibyśmy zatem rozpoczynającą się jeszcze w renesansie narodową myśl pedagogiczną, która kontynuowana w oświeceniu, znalazła kulminację w okresie romantyzmu. Jeszcze w średniowiecznej Polsce powstał pełny zarys systemu pedagogicznego, zawarty w dziele Konrada Bitschina De vita coniugali. Ponieważ jednak jego autorem był Niemiec, to wspomnianą pracę uznaje się za pierwszą napisaną u nas pedagogikę. Natomiast pierwszym polskim uczonym, który opracował te zagadnienia, tworząc tym samym zręby narodowej pedagogiki, był właśnie Sebastian Petrycy z Pilzna 5 .

Uzasadniając swoje stanowisko, Wąsik starał się wykazać wyższość koncepcji pedagogicznej filozofa $\mathrm{z}$ Pilzna nad przemyśleniami innych polskich autorów doby renesansu podejmujących kwestie wychowania. Petrycy, zdaniem Wąsika, górował

${ }^{2}$ Przy czym przez kompletny system pedagogiczny rozumiał koncepcję obejmującą wychowanie fizyczne, moralne i umysłowe w poszczególnych fazach rozwoju: dzieciństwo, okres chłopięcy i młodzieńczy.

${ }^{3}$ „Nie ulega wątpliwości, że autor Chowanny reprezentuje pewną postać naszej pedagogiki narodowej. Oto główne etapy rozwoju tej myśli wychowawczej. [...] Pierwszym autorem, który podjął u nas to zadanie, był Petrycy z Pilzna. Opracował on ten system w duchu renesansowego Humanizmu na samym początku XVII w. w epoce rozkwitu Rzeczpospolitej. W XVIII stuleciu, w dobie chylącego się do upadku państwa polskiego, kontynuatorami byli współtwórcy KEN, którzy znakomicie rozwiązali ten przedmiot $\mathrm{w}$ typie kultury Oświecenia. Otóż w XIX w. uczynił to właśnie Trentowski. Przejął on pewne idee wychowawcze od Komisji, które wobec warunków, jakie wytworzyły się w ówczesnej Polsce porozbiorowej, zmodernizował w duchu czasu i pogłębił filozoficznie w terminach idealizmu w stylu romantycznym". Wiktor Wąsik, Historia filozofii polskiej, t. 2 (Warszawa: Instytut Wydawniczy Pax, 1966), 261.

${ }^{4}$ Sławomir Sztobryn, „Wiktor Wąsik jako historyk filozofii wychowania”. W: Uniwersalizm i regionalizm pedagogiki filozoficznej, red. Sławomir Sztobryn, Dariusz Stępkowski (Łódź: Towarzystwo Pedagogiki Narodowej im. Bronisława F. Trentowskiego, 2017), 377.

${ }^{5}$ Wąsik stwierdza, że pomimo podjęcia przez A. Frycza Modrzewskiego w De Republica emendanda problemu reformy szkół nie rozwinął on w oryginalny sposób systemu wychowania, ponadto brak praktyki w zawodzie nauczycielskim sprawił, że „zagadnienia pedagogiczne nigdy go nie interesowały” i podejmował je z pobudek politycznych, kładąc nacisk nie tyle na wychowanie w ogóle, co na reformę szkolnictwa. Ponadto Modrzewski jest mało samodzielny w odniesieniu do wychowania fizycznego i umysłowego. Por. Wiktor Wąsik, System pedagogiczny Sebastiana Petrycego z Pilzna (Warszawa: Akademia Teologii Katolickiej, 1968), 21. 
nad nimi bądź wykształceniem, bądź doświadczeniem, bądź też głębią myśli czy wreszcie systematycznością ujęcia. Wąsik zwracał uwagę na pewne cechy wspólne przemyśleń wymienionych wyżej twórców narodowej pedagogiki, jak praktyczne nastawienie ${ }^{6}$, będące, jak wiadomo, specyficznym rysem uprawianej przez Polaków filozofii, czy postulat uwzględnienia naszego narodowego charakteru w procesie wychowywania?.

Ów praktyczny aspekt zaproponowanej pedagogiki widoczny jest chociażby w podejmowaniu szczegółowych kwestii związanych z kształtowaniem osobowości wychowanka. Przykładem może być dyscyplinowanie. Petrycy zasadniczo był przeciwnikiem kar cielesnych, uważając, że jeśli do poprawy nie wystarczy upominanie, to najprawdopodobniej najsurowsze kary cielesne również nie odniosą skutku. Można się do nich uciekać jedynie w ostateczności. Pisze też o konieczności uwzględnienia indywidualności wychowanka i stosowania takich metod, które w danym przypadku okazują się najbardziej odpowiednie, unikać natomiast schematycznego podejścia:

Jako w inszych rzeczach, tak i w ćwiczeniu dziatek mierność i baczenie ma być, abyśmy nie wykroczyli granic karania: nie bić nazbyt, ani też pobłażać nazbyt. Uważać też potrzeba dziecinne dowcipy: jeśli biciem, jeśli chwałą, jeśli czaczkami richlej naprwieni będą. Zapalczywości i gniewu jako też innych namiętności porywczej chronić się trzebå .

O praktycznym nastawieniu teorii wychowawczej decyduje przede wszystkim jej zorientowanie na cel. Ten rys pedagogiki będzie widoczny przy omawianiu poszczególnych etapów wychowania, które zostaną zaprezentowane niżej. Wydaje się jednak, że warto poprzedzić je choćby krótkim szkicem poglądów Petrycego dotyczących możliwości otwierających się przed procesem kształtowania młodych ludzi oraz ograniczeń, jakim on podlega.

Renesansowy uczony był przekonany o doniosłej roli wychowania, które w zasadniczy sposób kształtuje osobowość podopiecznego, mogąc przezwyciężyć nawet ograniczenia wynikające z różnych temperamentów. Dzięki wychowaniu natura człowieka może być niemal dowolnie modyfikowana: dzięki wychowaniu wady

6 „Ten praktycyzm, tj. wyższość działalności życiowej nad teoretycznymi rozważaniami, jest charakterystyczny nie tylko dla Trentowskiego i nie tylko dla współczesnych mu polskich myślicieli, ale i dla całej filozofii polskiej, a więc zarówno dla nowszej jak i staropolskiej”. Wąsik, Historia, t. 1, 260.

7 „Polskość systemu wychowania rozwiniętego w Chowannie miała być wynikiem nie tylko ogólnej koncepcji filozofii uniwersalnej, ale nadto system ten powinien być oparty w zamierzeniu autora na rozpoznaniu charakteru narodu polskiego. Ażeby tego umiejętnie dokonać, tj. wychować należycie dzieci polskie na dobrych synów ojczyzny, należy rozpoznać „wady narodowe”, bo „wielkie ma nasz naród wady, ale i wielkie cnoty". Wąsik, Historia, t. 2, 253. Wąsik, jak się wydaje, starał się dodatkowo uargumentować swoją opinię o „pierwszeństwie” Petrycego względem innych staropolskich autorów (Frycz), wskazując na jego samodzielność wobec myśli Arystotelesa, którego wyjściowe założenia przejął, ale rozwinął i rozbudował systematycznie szczególnie dla potrzeb teorii pedagogiki, na co nie zdobyli się pozostali uczeni korzystający ze Stagiryty. Por. Wąsik, System, 118-119.

8 Tamże, 127. 
można przekształcić $\mathrm{w}$ zalety ${ }^{9} \mathrm{Z}$ drugiej jednak strony wrodzone predyspozycje również odgrywają niebagatelną rolę. Indywidualność młodego człowieka jest zatem czynnikiem w istotny sposób determinującym końcowy efekt procesu wychowania, dlatego nie można jej ignorować ${ }^{10}$. W polskich zaś realiach, zdaniem Petrycego, wyjątkowo podatna na wychowanie jest, charakteryzująca się dużym potencjałem intelektualnym, młodzież szlachecka. Dlatego ewentualne zaniedbanie kształtowania tej warstwy byłyby szczególnie szkodliwe społecznie. Petrycy utożsamiał wręcz szlachectwo z posiadaniem pewnych zadatków, które pod kierunkiem wychowawcy rozwiną się w cnoty, co oczywiście miało przesądzać o tym, że wysiłek pedagogiczny okazałby się w takim przypadku wyjątkowo owocny. Ostatecznie jednak, jakkolwiek wpływ wychowania jest nie do przecenienia, to, jak wyżej wspomniano, w znacznym stopniu jego efekty uzależnione są od indywidualności wychowanka. Stąd postulat bacznej obserwacji celem dokładnego rozpoznania wrodzonych zdolności wychowanka i odpowiedniego pokierowania jego rozwojem ${ }^{11}$.

Petrycy uznał, że stosownie do wieku w procesie wychowania człowieka wyróżnić można trzy etapy i odpowiednio do nich dostosować kształcenie. W okresie obejmującym pierwszych siedem lat życia główny nacisk położyć należy na wychowanie fizyczne: „co pierwej bywa na świecie to też pierwej potrzeba ćwiczyć”12.

$\mathrm{W}$ tej dziedzinie na pierwszy plan wysuwają się działania mające na celu ochronę zdrowia wychowanka, które dominują w pierwszym okresie, chociaż nie mogą wyłącznie się doń ograniczyć. Wąsik zauważył, że ta część pedagogiki została przez Petrycego opracowana wyjątkowo starannie. Kwestie odżywiania, ubioru, snu, hartowania, gier i zabaw, ćwiczeń fizycznych przedstawił w sposób kompletny, $\mathrm{z}$ wykorzystaniem własnego doświadczenia jako lekarza i pedagoga. Pomimo widocznego w poszczególnych dziedzinach wychowania fizycznego rygoryzmu pojawił się postulat zachowania pewnej elastyczności, gdyż w przeciwnym razie, nawykły do uregulowanego trybu życia organizm, mógłby stać się podatny na różne schorzenia, np. w wypadku wojny, która uniemożliwiałaby przestrzeganie określonych zasad. Petrycy opowiadał się za różnicowaniem wychowania już na tym pierwszym jego poziomie $\mathrm{w}$ zależności od specyfiki przyszłego zawodu ${ }^{13}$.

9 „Otóż najwyraźniej potęgą wychowania jest to, że w ostatecznym kształtowaniu się osobowości ludzkiej natura ludzka może być wprost dowolnie modyfikowana. Wobec tego pozornie szkodliwe cechy indywiduum, np. wybujałe namiętności, mogą stać się podstawą do wielkich osiągnięć pedagogicznych.: „Jako też wiele chwastów się rodzi na bujnym ogrodzie, jednak te chwasty są znakiem dobrej ziemi, gdzie będzie wyplewione; tak też namiętności same przez się złe wielki dowcip znaczą, nie zły, by tylko dobre wychowanie przystąpiło". Tamże, 43.

${ }^{10}$ R. Matsili, Człowiek w twórczości Petrycego z Pilzna (Łódź: Wydawnictwo Akademii Humanistyczno-Ekonomicznej, 2008), 85-86.

${ }_{11}$ „Rozważania na ten temat przeprowadził Petrycy naszym zdaniem bardzo wnikliwie, z dużą wiedzą o konstytucji duchowej człowieka”. Wąsik, System, 45.

12 Tamże, 92.

13 „Dzieciom, którzy mają potym rządzić Rzeczpospolitą, powinne jest ćwiczenie ciała, aby i rozumem, i ciałem służyli Rzeczypospolitej. [...] A którzy nie mają woli rządzić Rzeczpospolitą, jako księża, filozofowie, ci nie potrzebują ćwiczenia ciała, tylko ile zdrowiu należy". Tamże, 92. 
Ćwiczenia fizyczne mają znaczenie także dla rozwoju intelektualnego jako niezbędna rekreacja, usposabiająca wychowanków do pracy umysłowej. Rozwój fizyczny jest zatem środkiem do osiągnięcia wysokiego poziomu umysłowego ${ }^{14}$. Pierwszorzędnym celem gimnastyki jest jednak, w myśli Petrycego, służba ludzkiemu zdrowiu. W ten sposób antycypuje on późniejsze propozycje Locke’a oraz, zdaniem Wąsika, wysuwa się na czoło staropolskich autorów, z których wielu nie przykładało wystarczającej wagi do wychowania fizycznego ${ }^{15}$.

Ten pierwszy etap był, jak już widzieliśmy, podstawą do znacznie bardziej doniosłego wychowania moralnego mającego olbrzymie znaczenie dla życia zarówno indywidualnego, jak i społecznego. Był to okres „dzieciństwa doskonałego” trwającego od 7 do 14 roku życia. W tym czasie koncentrując się na doskonaleniu woli, pedagog powinien kształtować takie zalety, jak prawdomówność, życzliwość, posłuszeństwo (zwłaszcza w perspektywie przestrzegania prawa). Dlatego ważne jest, żeby nie pobłażać zwłaszcza w odniesieniu do ciężkich wykroczeń (co szczególnie w odniesieniu do młodzieży szlacheckiej było niechlubną praktyką). Ukracać swawolę poprzez roztropne ograniczanie woli wychowanka i przyzwyczajanie go do podporządkowania się dorosłym: „aby właściwie postępować należy powodować się rozumem, ale dziecko nie ma jeszcze swego własnego »baczenia «, dlatego też należy nim kierować"16. Tym niemniej Petrycy jest zwolennikiem łagodnego wdrażania dzieci do posłuszeństwa. Istotne jest także kształtowanie pracowitości, szczególnie w kontekście będącego narodową wadą lenistwa. Zasadnicze znaczenie ma przekonanie o istotnym wpływie na dorosłe życie tego, co wpojono wychowankowi: „czym skorupka za młodu nasiąknie, tym na starość trąci”. Zdaniem Petrycego ten okres rozwoju jest szczególnie istotny dla kształtowania obyczajów, a ukonstytuowana wówczas osobowość zadecyduje o całym dalszym życiu młodego człowieka. Rozpoczęte w „dzieciństwie doskonałym” wychowanie moralne winno być kontynuowane w okresie późniejszym, podobnie jak wychowanie fizyczne nie mogło ograniczyć się do się pierwszych siedmiu lat życia. Chodzi jednak o odpowiednie rozłożenie akcentów.

W związku z koniecznością korygowania złych skłonności pozostaje zagadnienie kształcenia charakteru. Petrycy rozumiejąc charakter jako przyzwyczajenie do dobrego („nałóg dobry”), konsekwentnie odchodził od deklarowanego w filozofii praktycznej (także w pedagogice) intelektualizmu, podkreślając potrzebę wyrobienia przyzwyczajenia - ugruntowania w dobrem poprzez ćwiczenie wychowanka ${ }^{17}$.

14 „Należy dbać o najstaranniejsze wychowanie fizyczne, bo ono właściwie i zasadniczo, nie stanowiąc celu samego w sobie, daje zdrowie, a więc podstawę do osiągnięcia wysokiego rozwoju umysłowego. Bo zdrowie, jak to wynika z przytoczonych przez nas cytatów z naszego arystotelika, jest potrzebne wszystkim stanom i zawodom, natomiast specjalne uzdolnienia fizyczne są potrzebne lub konieczne tylko niektórym”. Tamże, 94.

15 Tamże, 99.

16 Tamże, 105.

17 „Powoli ten wyraźny intelektualizm pedagogiczny rozsadzają u naszego pedagoga elementy irracjonalne, które $\mathrm{z}$ różnych stron wdzierają się w tę jednolitą systematycznie koncepcję. Już tu mówi o »rozumie 
Chociaż Petrycy był zdecydowanym zwolennikiem ustroju stanowego i poglądy te znalazły wyraz w jego pedagogice, to w zaproponowanej koncepcji wychowania fizycznego oraz moralnego różnice wynikające z przynależności do poszczególnych stanów nie są bardzo wyraźne. Kształcenie umysłowe jednak, odbywające się między 14 a 21 rokiem życia, ukazuje już w sposób wyraźny Petrycego jako zwolennika ustroju stanowego. Nie oznacza to jednak, że wyższe wykształcenie rezerwuje wyłącznie dla szlacheckich potomków. Prawo do studiów powinni mieć wszyscy niezależnie od pochodzenia, a nawet stanu posiadania, zwłaszcza gdy wykazują się intelektualnymi zdolnościami. Postulowane są nawet państwowe stypendia dla bardzo dobrze zapowiadającej się ubogiej młodzieży.

Petrycy zdawał sobie sprawę $\mathrm{z}$ tego, że odpowiednia formacja intelektualna ma kluczowe znaczenie dla obowiązków, jakie w przyszłości adepci mają podjąć. To właśnie zadania, którym będą musieli stawić czoła, w znacznym stopniu miały zdeterminować program kształcenia. Ponieważ zaś przyszłość zależała najczęściej od pochodzenia, ten etap wychowania charakteryzował się stanowością, co nie stawało w sprzeczności z postulatem demokratyzacji oświaty. Petrycy podkreślał bowiem, że istnieją dyscypliny potrzebne wszystkim warstwom społecznym, wśród których znajduje się nauka wiary - mająca być wpajana poprzez przyzwyczajenie, praktyki, a nie czysto teoretycznie ${ }^{18}$. Wśród nauk świeckich uniwersalne przeznaczenie mają, jak się wydaje: gramatyka, dialektyka i retoryka - trivium, którego, jak należy sądzić, uczyć się powinny dzieci szlacheckie, potomkowie zamożniejszych rodzin oraz, w drodze wyjątku, pozostali. Wyraźne zróżnicowanie kształcenia w zależności od przynależności stanowej rozpoczyna się zatem dopiero po 14 roku życia.

Program nauczania w okresie młodzieńczym powinien obejmować fizykę, matematykę, etykę i politykę. Petrycy odchodzi zatem od tradycyjnie proponowanego quadrivium, zbliżając się do rozwiązania typowego dla renesansu, gdzie przyjmowano podział na nauki ścisłe i filozofię praktyczną. W tej ostatniej eksponowano element parenetyczny, pomijając uwagi programowe i dydaktyczne, a więc wyraźnie orientując ją praktycznie ${ }^{19}$.

Stanowy charakter kształcenia intelektualnego widoczny był wyraźnie w naukach świeckich. Wykształcenie proponowane szlachcie miało charakter humanistyczny i Petrycy nie postulował pogłębionego studium poszczególnych dziedzin, tylko ogólne zapoznanie się z nimi. Chodziło bowiem o wyrobienie intelektualnej sprawności

dobrze rozkazującym«, a nie wystarcza mu rozum »mądrze rozkazujący«, zaś cokolwiek dalej o »rozumie ugruntowanym «; pierwszy z tych terminów wskazuje na czynnik woluntarystyczny, który łączy się z intelektualnym, a w drugim tę samą rolę odgrywa przyzwyczajenie". Tamże, 113.

${ }_{18}$ Wśród autorów staropolskich wskazania dotyczące nauki religii należą do rzadkości, co, zdaniem Wąsika, wynikało z przekonania, że znajduje się ono w kompetencjach duchownych. Obszerne potraktowanie problematyki religijnej przez Reja nie idzie w parze z propozycją rozwiązań szczegółowych - jak i w jakim zakresie należy dzieci uczyć religii, i jest adresowane głównie do dorosłych. Sobieski natomiast stworzył raczej rodzaj regulaminu zawierającego przepisy, podane bez uzasadnień. To, zdaniem Wąsika, decyduje o wyjątkowości Petrycego. Por. tamże, 168.

19 Tamże, 172. 
niezbędnej do uczestniczenia w życiu publicznym, a nie o przygotowanie do pracy naukowej. Natomiast przyszli uczeni, którzy mieliby się rekrutować przede wszystkim spośród mieszczan, winni się gruntownie kształcić. Wąsik zwracał uwagę, że postulat praktycznego zorientowania formacji intelektualnej był charakterystyczny dla siedemnastowiecznej kultury, a w sposób dojrzały znalazł wyraz w myśli Johna Locke'a ${ }^{20} \mathrm{w}$ formie realizmu społecznego, którego istotę streszcza starożytne adagium: non scholae, sed vitae discimus.

Formowany w procesie wychowania człowiek należy do szerszej społeczności, dlatego przebieg, a zwłaszcza rezultat tego procesu nie mogą być obojętne państwu. Jak wiadomo, problem rozumienia celu instytucji oświatowych ma długą i bogatą historię obejmującą zarówno platoński ideał przygotowania posłusznych i pożytecznych obywateli, jak i doktryny anarchistyczne. Stanowisko Petrycego w tej kwestii było wyważone. Pedagogika w jego ujęciu nie tylko nie ograniczała się do ukształtowania sprawnie działających komórek organizmu państwowego, kładąc nacisk na rozwój indywidualności, ale też odrzucała monopol państwa w procesie wychowania, podkreślając rolę rodziny w przysposobieniu młodzieży do przyszłych zadań w sferze publicznejej.

W realiach siedemnastowiecznej Polski - ze względu na złotą wolność szlachecką - jednym z najbardziej pożądanych efektów wychowania było posłuszeństwo prawu. Stąd pojawiło się przekonanie, że adepci powinni być w nie wdrażani już $\mathrm{w}$ rodzinnym domu, najpierw $\mathrm{w}$ relacjach $\mathrm{z}$ rodzicami, potem $\mathrm{w}$ życiu publicznym. Pogląd o istotnej zależności między jakością kształcenia a poziomem życia obywatelskiego w państwie pojawił się w polskiej myśli już w XVI w. ${ }^{22}$ i dojrzewał aż do osiemnastego stulecia, kiedy to skonkretyzował się w Komisji Edukacji Narodowej, będącej organem I Rzeczypospolitej odpowiedzialnym za polskie szkolnictwo.

\section{II}

Charakteryzujący się praktycznym nastawieniem renesansowy realizm w pedagogice był już bliski kulturze Oświecenia ${ }^{23}$, która w I Rzeczypospolitej, korzystając z wzorców zachodnioeuropejskich, posiadała swoje specyficznie polskie zabarwienie,

20 Bardzo wiele miejsca poświęcił Wąsik wykazywaniu zbieżności poglądów naszego myśliciela ze stanowiskiem późniejszego o niemal całe stulecie angielskiego filozofa, zaznaczając, że z jednej strony nie może być mowy o wykorzystaniu pomysłów pilzneńskiego uczonego przez autora Myśli o wychowaniu, z drugiej natomiast sugerując, że gdyby polscy oświeceniowi filozofowie lepiej znali rodzimą myśl pedagogiczną, mogliby odwołać się wprost do niej zamiast sięgać po „angielskiego Petrycego”.

${ }^{21}$ Wąsik zauważa, że ten wątek jest oryginalnym pomysłem Petrycego, który odchodzi w tym momencie od Arystotelesa, wykazując się samodzielnością. Wąsik, System, 48.

22 Wąsik wymienia Mariciusa i Frycza Modrzewskiego jako przykład autorów dostrzegających zależność jakości życia publicznego, stanowionych praw od systemu oświaty, zaznaczając, że „pogląd ten jest wyjątkowo stałym elementem polskiej myśli politycznej i pedagogicznej”. Tamże, 47.

23 Tamże, 187. 
co zresztą wpisywało się w hasła tej epoki, głoszącej potrzebę opracowywania narodowych koncepcji wychowania. Dorobek naszej najbardziej reprezentatywnej instytucji wychowawczej tej epoki, jaką była Komisja Edukacji Narodowej, poprzedziła działalność Stanisława Konarskiego. Istotna z punktu widzenia omawianej tu pedagogiki narodowej jest opinia Wąsika podkreślająca oryginalność koncepcji Konarskiego adekwatnej do warunków polskich. Podejście takie było wyrazem oświeceniowych tendencji do uwzględniania w refleksji pedagogicznej rodzimych realiów, wręcz do tworzenia narodowych filozofii wychowania. Tendencja ta znalazła kontynuację w poglądach Staszica i Kołłątaja, którzy wraz z innymi autorami opracowali ją w ramach programu KEN w duchu oświeceniowym, zyskując dzięki temu jednorodność, mimo różnic występujących w poglądach poszczególnych przedstawicieli ${ }^{24}$. Dominował, charakterystyczny jeszcze dla myśli Petrycego, praktyczny charakter kształcenia: „więcej zależy państwu na uczciwych ludziach i dobrych obywatelach aniżeli na wielkich mówcach, poetach, matematykach i filozofach" 25 . Utylitarystyczne nastawienie, określane mianem realizmu społecznego, przejawiało się zatem w odejściu od realizowania ambicji teoretycznych i doborze przedmiotów zorientowanym na indywidualny i zbiorowy pożytek uczniów. Nauczyciele byli zobowiązani do przedstawiania korzyści, jakie osiągną ich podopieczni, przyswajając sobie wiedzę ${ }^{26}$.

Wspólne z poglądami Petrycego było również, typowe dla oświecenia, przekonanie o nieograniczonych niemal możliwościach wychowania, wyrażane między innymi przez Staszica: „Ludzie z natury nie są ani złymi ani dobrymi [...] edukacja złymi lub dobrymi uczynić ich może" ${ }^{\prime 2}$. Chociaż bowiem pewne wrodzone tendencje, jak dążenie do szczęścia bądź unikanie cierpienia pozostaną niezmienione, to edukacja może istotnie modyfikować wartościowanie: „ona tak nas przerobić umie, że istotne człowieka nieszczęście obieramy za naszą szczęśliwość”28.

Kołłątaj bardziej optymistycznie zdaje się postrzegać ludzką naturę, stwierdzając, że jej samorzutny rozwój z wykorzystaniem przyrodzonych środków prowadzi do urzeczywistnienia dobra ${ }^{29}$. Podobnie jednak jak Staszic, zauważa, że owa natura podlega zasadniczym zmianom - w istotny sposób modyfikują ją, kształtowane od dzieciństwa, przyzwyczajenia („nałogi”). To one: dobre lub złe, stając się naszym alter ego, przesądzają o tym, jakimi ludźmi jesteśmy. Trudno nie zauważyć, że konsekwencją rysującej się w ten sposób antropologii musi być

24 Por. Wąsik, Historia, t. 1, 259.

25 Tamże, 267.

26 Tamże, 267.

27 Stanisław Staszic, „Uwagi nad życiem Jana Zamoyskiego”. W: tegoż, Pisma filozoficzne i społeczne, t. 1 (Kraków: PWN, 1954), 16.

28 Tamże, 16.

29 „Człowiek jest z przyrodzenia do dobrego skłonny i tak własnymi potrzebami naglony, że byle tylko szedł za ich uczuciem, byle starał się zaspakajać one środkami, jakie mu przyrodzenie wskazuje, byle używał do tego swych należytości i dopełniał ściśle nieoddzielne od nich powinności, nie może być złym”. Hugo Kołłątaj, Porządek fizyczno-moralny (Kraków: PWN, 1955), 3. 
przekonanie o wielkich możliwościach, ale też niełatwych wyzwaniach stojących przed wychowaniem. W związku z tym pojawia się pytanie, czy sposób, w jaki ma ono przebiegać, koresponduje $\mathrm{z}$ wcześniejszą propozycją sformułowaną $\mathrm{w}$ dobie renesansu, czy też w związku z zasadniczo zmienionymi realiami będzie od niej odbiegać?

Niezmieniony, jak się wydaje, pozostanie charakterystyczny dla polskiej pedagogiki postulat integralnego podejścia do wychowania, który odnajdujemy u Staszica: "człowiek do edukacji ma dwie rzeczy: duszę i ciało" ${ }^{30}$. Chociaż można odnieść wrażenie, że w antropologii opowiada się za prymatem tej pierwszej („Ciało tylko myśli wykonywa i podług nich porusza się”), to w przypadku wychowania nie tylko uznaje za poważny błąd przeakcentowanie „doskonalenia” duszy kosztem ciała, ale ćwiczenie ciała wprost przedkłada nad każdą inną umiejętność z wyjątkiem nauki moralnej. Ostatecznie sformułowany został postulat zachowania złotego środka: „aby edukacja nie była edukacją samego tylko ciała albo samej tylko duszy, ale człowieka" ${ }^{\prime 1}$.

Sprawność fizyczna potrzebna jest nie tylko do sprostania obowiązkom wynikającym $\mathrm{z}$ wykonywanego zawodu, ale przede wszystkim do efektywnego wypełniania służby wojskowej, tak bardzo potrzebnej w kontekście zagrożenia niepodległości.

Ścisły związek ciała z duszą uzasadniał z kolei konieczność powiązania edukacji fizycznej z niezwykle wysoko cenioną formacją moralną ${ }^{32}$. W opracowaniach dotyczących oświeceniowych koncepcji wychowania moralnego zwraca się uwagę na inspiracje fizjokratyzmem, przejawiające się w oparciu nauki moralnej na psychologiczno-socjologicznej analizie egzystencji ludzkiej ${ }^{33}$. W tym duchu formułował Staszic podstawowe obowiązki moralne, spośród których na pierwszy plan wysuwała się praca: „Niechaj ta nauka najwięcej a jak najjaśniej powtarza młodemu, że [...] pierwszym obowiązkiem człowieka jest pracować, że tylko poprzez pracę staje się obywatelem użytecznym, że w każdym stanie próżnowanie czyni człowieka szkodliwym i sobie samemu i innym" ${ }^{34}$.

Dalsza analiza porządku społecznego doprowadzała do wniosku, że jest rzeczą szlachetną dzielenie się owocami swej pracy z innymi. Ze względu zaś na wzajemne zależności pomiędzy poszczególnymi obywatelami: „jeden nie może szkodzić drugiemu, aby tym samym nie krzywdził towarzystwa całego i nie szkodził samemu sobie [...] nauka moralna ten oczywisty z tego wniosek poda za krótkie, a powszechne czynności prawidło: „co tobie nie miło tego nie czyń drugiemu” ${ }^{35}$.

\footnotetext{
30 Staszic, Uwagi, 27.

31 Tamże, 27.

32 „Nauka moralna jest ze wszystkich najpierwszą”. Tamże, 18.

33 Stanisław Janeczek, „Ideały wychowawcze w szkołach Komisji Edukacji Narodowej - między »nauką moralną" a "chrześcijańską wiedzą «". W: Humanitas i Christianitas w kulturze polskiej, red. Mirosława Hanusiewicz-Lavalle (Warszawa: Wydawnictwo Neriton, 2009), 310.

34 Staszic, Uwagi, 18.

35 Tamże, 18.
} 
Tak oświecony człowiek zaraz uczuje tę oczywistą tego wniosku przyczynę: „bo to samo stanie się tobie samemu"36.

Moralne wychowanie nie może być jednak ograniczone do najlepiej choćby opracowanej i wyłożonej teorii. Wraz z nią musi pójść praktyka, o którą zatroszczyć się powinna szkoła: „Trzeba, aby takie godziny moralnej lekcji były, w których by dzieci to wykonywały, czego ich prawidłami uczono" ${ }^{37}$. Istotnym wzmocnieniem motywacji dobrego postępowania była formacja religijna. Wprawdzie w literaturze przedmiotu nie brakowało opinii o emancypowaniu się moralności od religii jako procesie charakterystycznym dla kultury oświecenia, to jednak stwierdzić trzeba, że równolegle uznawano wprost potrzebę odwołania się do autorytetu chrześcijaństwa, aby prawom i powinnościom moralnym zapewnić większą powagę ${ }^{38}$. Warto również wspomnieć, że nawet podkreślający owo usamodzielnianie się moralności Wąsik poglądy dotyczące wychowania moralnego zamieścił w rozdziale poświęconym filozofii religii.

Charakterystyczny dla dydaktyki KEN jest również związany z utylitaryzmem (realizmem społecznym) postulat rugowania elementów metafizycznych zwłaszcza z przyrodoznawstwa. W logice widoczny jest splot filozofii zdrowego rozsądku z sensualistyczną logiką preferujący jej nauczanie pod kątem praktycznego zastosowania. Wreszcie w nauczaniu stosowana ma być metoda poglądowa („działania arytmetyki na jakich rzeczach, pieniądzach okazywać będzie" ${ }^{39}$ ). Nauka winna się opierać na rozumiejącym poznaniu rzeczywistości, a nie pamięciowym przyswojeniu treści i przyjmowaniu za autorytetem. Pojawiają się również postulaty wprowadzania nauczania zabawiającego ${ }^{40}$.

Celem wychowania ma być pożytek indywidualny i zbiorowy, a więc człowiek, podobnie jak w refleksji Petrycego, ma się kształcić non scholae, sed vitae. Zasada ta obowiązuje również jako kryterium doboru języka obcego ${ }^{41}$. W reformie szkół wyższych (autorstwa Kołłątaja) usunięto filozofię, zastępując ją zbiorem nauk opartych na prawie natury, co najprawdopodobniej było przejawem niechęci wobec scholastyki, którą inaczej trudno byłoby wyeliminować, biorąc pod uwagę formację intelektualną oraz preferencje nauczycieli akademickich. Układ nauk wyrażał sensualistycznego i empirycznego ducha epoki, kładąc nacisk na laboratoria, kliniki i urządzenia do zajęć praktycznych.

Polska pedagogika oświeceniowa pozostając w łączności z zachodnioeuropejską myślą, starała się wyjść naprzeciw narodowym potrzebom, z których na czoło wysuwała się konieczność obrony niepodległego bytu. Nawet utrata państwowości nie umniejsza znaczenia dokonań, jakie wówczas osiągnięto.

\footnotetext{
36 Tamże, 18-19.

37 Tamże, 20.

38 Janeczek, Ideały, 311.

39 Wąsik, Historia, t. 1, 266.

40 Tamże, 266-267.

41 Tamże, 267-268.
} 


\section{III}

Doświadczenie przedłużającej się niewoli oraz klęski zrywu narodowego, jakim było powstanie listopadowe, spowodowało wzrost zainteresowania refleksją, która przyczyniłaby się do utrzymania polskiej tożsamości w skrajnie trudnych warunkach panujących po utracie państwowości. Efektem tego było powstanie w dobie romantyzmu polskiej filozofii narodowej. Wśród jej przedstawicieli istotne miejsce, także ze względu na interesującą nas problematykę pedagogiczną, zajmuje Bronisław Ferdynand Trentowski, autor monumentalnego dzieła zatytułowanego Chowanna. W przypadku Trentowskiego jego filozofia uniwersalna, nazywana też narodową ${ }^{42}$, warunkowała koncepcję pedagogiki, która przezwyciężając jednostronności dotychczasowych propozycji, stawiała sobie za cel wychowanie człowieka rzeczywistego. Zgodnie z projektem autora Chowanny uniwersalna filozofia, będąca dziełem polskiego ducha, miała połączyć w wyższej syntezie dokonania empiryzmu i myśli spekulatywnej. Hołdująca tej samej zasadzie pedagogika, korzystając z metody różnojedni, chciała zrealizować ideał bożoczłowieczeństwa, polegający na przeprowadzeniu wychowanka od stadium bóstwa in potentia do bóstwa in actu. Ten pierwotny stan, od którego miało rozpocząć się wychowanie, poprzedzony był koniecznym procesem stworzenia, w wyniku którego zaistniał człowiek. Akt stwórczy, zdaniem Trentowskiego, polegał na przejściu z bezwarunkowości i bezwzględności Stwórcy do względności i warunkowości stworzenia „zawarowanego” czasem i przestrzenią. Była to swoista degradacja ontyczna, której efekt Trentowski określał mianem grzechu pierworodnego, interpretując go w kategoriach środka niezbędnego do wytłumaczenia możliwości rozwoju człowieka, co z kolei było warunkiem sine qua non pedagogiki ${ }^{43}$. Ufundowana w ten sposób koncepcja pedagogiczna wyrażała przekonanie o olbrzymiej potencjalności wychowanka, który odpowiednio kierowany ma nie tylko przerosnąć swojego mistrza, ale osiągnąć doskonałość mierzoną miarą bożoczłowieczeństwa.

Narodowy charakter pedagogiki wynikał nie tylko z jej zespolenia z filozofią polską, ale był również efektem rozpoznania charakteru narodu polskiego wielkich narodowych wad i cnót. Wśród tych ostatnich na czoło wysuwały się przywiązanie do wolności i miłość ojczyzny. Głównymi wadami były natomiast przesądy, brak tolerancji, lekceważenie oświaty oraz zamknięcie się w narodowej przeszłości i poszukiwanie tam wzorów do realizowania ${ }^{44}$.

42 Ewa Starzyńska-Kościuszko, „Uniwersalizm i narodowość filozofii i pedagogiki Bronisława Ferdynanda Trentowskiego”. W: Uniwersalizm i regionalizm pedagogiki filozoficznej, red. Sławomir Sztobryn, Dariusz Stępkowski (Łódź: Towarzystwo Pedagogiki Filozoficznej „Chowanna”, 2017), 87-88.

43 Rafał Charzyński, „Antropoteistyczna podstawa etyki Trentowskiego”. W: Dziedzictwo Bronisława Trentowskiego. W 150-lecie śmierci Filozofa, red. Sławomir Sztobryn (Łódź: Towarzystwo Pedagogiki Filozoficznej „Chowanna”, 2019), 132.

44 Wąsik, Historia, t. 2, 253. 
Wychowanie miało mieć charakter integralny, obejmując wszystkie władze człowieka: ciało, duszę i jaźń. Kształtowanie pierwszego z elementów obejmowało wychowanie fizyczne, ale także wychowanie zmysłów, pamięci i rozumu. Odbywać miało się ono przy pomocy metody poglądowej, nauczania przygodnego i zabawiającego. Ograniczenie się jednak tylko do troski o ten wymiar było obarczone jednostronnością, prowadząc, by użyć sformułowania Trentowskiego, do ukształtowania jedynie realności wychowanka. Tymczasem należało rozwijać również to, co dotyczy duszy, a więc umysł, rozsądek i wyobraźnię, określanych jako idealność. Najistotniejsze jednak było wychowanie jaźni: „poznającej” (uwaga, rozwaga, „mysł”), „tlejącej” (uczucia, skłonności, chęci) i „działającej” (przedsięwzięcie, wykonanie, czyn ${ }^{45}$. Jakkolwiek właśnie w jaźni należy upatrywać czynnika będącego podstawą tożsamości jednostki, istoty człowieczeństwa, zespalającego cielesność i duchowość, a nawet przekraczającego to, co ludzkie ${ }^{46}$, to wychowawczym oddziaływaniem objęte miały być wszystkie wymiary człowieka.

„Człowiek rzeczywisty”, który jest podmiotem narodowej pedagogiki Trentowskiego, pojawić ma się jako efekt komplementarnego potraktowania dwu przeciwstawnych koncepcji wychowawczych. Pierwsza z nich powiązana $\mathrm{z}$ empiryzmem wychowuje człowieka realnego - egoistę, kierującego się w życiu osobistą korzyścią, oportunizmem. Z drugiej strony natomiast rozwija umiejętności praktyczne, uczy dbania o sprawność fizyczną i higienę, pomijając jednak sferę uczuć wyższych ostatecznie wychowuje, by użyć sformułowania Trentowskiego „człowieka realnego” - „moralnego szatana”. Znajdująca się na antypodach tej koncepcji pedagogika spekulacyjna, skoncentrowana na kształceniu zdolności zawartych w duszy, w miejsce pożytku stawia szlachetność, rozwijając entuzjazm i nadzieję, ignoruje zupełnie niezbędne do realizacji szczytnych celów środki. Rozwija między innymi fantazję („um”), która winna być poddana kontroli rozsądku, gdyż w przeciwnym razie prowadzi do nieszczęść, znanych z odległej historii: złota wolność, liberum veto, oraz niedawnej przeszłości - klęska powstania listopadowego. W efekcie pedagogika ta wychowuje „człowieka idealnego” - „moralnego anioła” oderwanego od realnego życia. Dopiero skojarzenie obu półprawd w projekcie uniwersalnej pedagogiki prowadzi do ukształtowania „człowieka rzeczywistego” realizującego ideał Bożoczłowieczeństwa. Jest on osobowością twórczą, zdolną do działania i samodzielną, co w koncepcji Trentowskiego stanowi o istocie zrealizowanego w człowieku bóstwa ${ }^{47}$.

45 Tamże, 253-254.

46 Wiesława Sajdek, „Doskonałość człowieka jako ideał wychowawczy. Na podstawie pism Bronisława Trentowskiego". W: Dziedzictwo Bronisława Ferdynanda Trentowskiego, 147-148.

${ }^{47}$ Ewa Starzyńska-Kościuszko, Bronisław Ferdynand Trentowski (1808-1969). Filozofia uniwersalna i myśli o „wyjarzmieniu” ojczyzny (Olsztyn: Wydawnictwo Uniwersytetu Warmińsko-Mazurskiego, 2018), 107-112. 
$\mathrm{W}$ ten sposób autor Chowanny wpisuje się w projekt narodowej pedagogiki, która korzystając z wzorców zagranicznych, starała się wypracować model zgodny z potrzebami polskiego ducha i odpowiadający aktualnym wyzwaniom.

\section{Zakończenie}

Przedstawione wyżej poglądy polskich uczonych nie tylko potwierdzają sformułowaną przez W. Wąsika tezę o istnieniu polskiej pedagogiki narodowej. Jest ona inspirowana myślą zachodnioeuropejską, jednakże programowo stara się wyjść naprzeciw aktualnym potrzebom społeczeństwa polskiego, chociażby poprzez zwalczanie naszych wad narodowych. Nie zamykając się w partykularyzmie, narodowa pedagogika potrafiła przybrać taki kształt, który wyrażał, chronił i przekazywał kolejnym generacjom to, co najbardziej wartościowe. Spójna z zachodnioeuropejskim i tendencjami jest integralna wizja wychowywania człowieka w jego wymiarze fizycznym, moralnym i intelektualnym. Otwarcie na wpływy zagranicznej refleksji nie pozbawia polskiej pedagogiki ambicji twórczego rozwijania rodzimej kultury, co widoczne jest zwłaszcza w pismach Petrycego z Pilzna czy Bronisława Trentowskiego, którzy wiele wysiłku wkładają w ukucie polskiej terminologii. Znamienne jest również i to, że pomimo zakorzenienia w tak różnych tradycjach filozoficznych owe koncepcje pedagogiczne wykazują istotną zbieżność dotyczącą zarówno optymistycznego poglądu na możliwości wychowania, jego celów, jak też, przynajmniej do pewnego stopnia, stosowanych środków. Kończąc, warto, jak się wydaje, postawić pytanie o kontynuację tej tradycji, pytanie o to, jaki kształt przybierze potencjalna spadkobierczyni naszej pedagogiki narodowej, jaka będzie polska pedagogika przyszłości.

St r e s z c z e n i e: Artykuł stara się wykazać słuszność tezy W. Wąsika o istnieniu pedagogiki narodowej. Poglądy wskazanych przez niego przedstawicieli przeanalizowane w powyższym tekście wykazują wiele istotnych cech wspólnych powtarzających się w stosunkowo odległych w czasie kontekstach historyczno-społecznych i kulturowych. Pozwala to na uchwycenie tej refleksji pedagogicznej z jednej strony jako specyficznie polskiej, z drugiej zaś inspirowanej myślą europejską i zharmonizowanej z nią.

Słow a klu c z o w e: polska pedagogika narodowa, Wiktor Wąsik, Sebastian Petrycy z Pilzna, Hugo Kołłątaj, Stanisław Staszic, Bronisław Trentowski

\section{Bibliografia}

Charzyński, Rafał. „Antropoteistyczna podstawa etyki Trentowskiego”. W: Dziedzictwo Bronisława Ferdynanda Trentowskiego. W 150-lecie śmierci Filozofa, red. Sławomir Sztobryn, 129-136. Łódź: Towarzystwo Pedagogiki Filozoficznej „Chowanna”, 2019. 
Janeczek, Stanisław. „Ideały wychowawcze w szkołach Komisji Edukacji Narodowej - między »nauką moralną" a "chrześcijańską wiedząu. W: Humanitas i Christianitas w kulturze polskiej, red. Mirosława Hanusiewicz-Lavalle, 293-318. Warszawa: Wydawnictwo Neriton, 2009.

Kołłątaj, Hugo. Porządek fizyczno-moralny. Kraków: PWN, 1955.

Matsili, Renata. Człowiek w twórczości Petrycego z Pilzna. Łódź: Wydawnictwo Akademii Humanistyczno-Ekonomicznej, 2008.

Sajdek, Wiesława. „Doskonałość człowieka jako ideał wychowawczy. Na podstawie pism Bronisława Trentowskiego". W: Dziedzictwo Bronisława Ferdynanda Trentowskiego. W 150-lecie śmierci Filozofa, red. Sławomir Sztobryn, 137-154. Łódź: Towarzystwo Pedagogiki Filozoficznej „Chowanna”, 2019.

Starzyńska-Kościuszko, Ewa. „Uniwersalizm i narodowość filozofii i pedagogiki Bronisława Ferdynanda Trentowskiego". W: Uniwersalizm i regionalizm pedagogiki filozoficznej, red. Sławomir Sztobryn, Dariusz Stępkowski, 8-113. Łódź: Towarzystwo Pedagogiki Filozoficznej „Chowanna”, 2017.

Starzyńska-Kościuszko, Ewa. Bronisław Ferdynand Trentowski (1809-1869). Filozofia uniwersalna i myśli o „wyjarzmieniu” ojczyzny. Olsztyn: WN UWM, 2018.

Staszic, Stanisław. „Uwagi nad życiem Jana Zamoyskiego”. W: tenże, Pisma filozoficzne i społeczne, t. 1, 9-172. Kraków: PWN, 1954.

Sztobryn, Sławomir. „Wiktor Wąsik jako historyk wychowania”. W: Uniwersalizm i regionalizm pedagogiki filozoficznej, red. Sławomir Sztobryn, Dariusz Stępkowski, 375-383. Łódź: Towarzystwo Pedagogiki Filozoficznej „Chowanna”, 2017.

Wąsik, Wiktor. Historia filozofii polskiej, t. 1-2. Warszawa: Instytut Wydawniczy Pax, 1958-1966.

Wąsik, Wiktor. System pedagogiczny Sebastiana Petrycego z Pilzna. Warszawa: Akademia Teologii Katolickiej, 1968. 